\title{
Gas Exchange, Water Status, and Growth of Pepper Seedlings Exposed to Transient Water Deficit Stress are Differentially Altered by Antitranspirants
}

\author{
Smiljana Goreta \\ Institute for Adriatic Crops, Put duilova 11, Split 21000, Croatia and Texas Agricultural \\ Experiment Station, Vegetable and Fruit Improvement Center, Texas A\&M University, \\ 1619 Garner Field Road, Uvalde, TX 78801 \\ Daniel I. Leskovar ${ }^{1}$ \\ Texas Agricultural Experiment Station, Vegetable and Fruit Improvement Center, Texas A\&M \\ University, 1619 Garner Field Road, Uvalde, TX 78801 \\ John L. Jifon \\ Texas Agricultural Experiment Station, Vegetable and Fruit Improvement Center, Texas A\&M \\ University, 2415 East Highway 83, Weslaco, TX 78596
}

Additional index words. ABA, AVG, abiotic stress, desiccation, ethylene, film-forming materials

\begin{abstract}
Aвstract. Successful field establishment of vegetable transplants often depends on the ability of young seedlings to tolerate various biotic and abiotic stresses after transplanting. Treatments that limit transpirational water loss could improve plant survival and stand establishment. In this study we evaluated growth and physiological responses of pepper (Capsicum annuum L.) seedlings to foliar application of chemical plant regulators [abscisic acid (ABA) and aminoethoxyvinylglycine (AVG)] or physical film-forming barriers [AntiStress (AS), Transfilm (TF), and Vapor Gard (VG)] during transient 4-day water deficit cycles. During two 4-day water deficit cycles, stomatal conductance $\left(g_{s}\right)$ and net $\mathrm{CO}_{2}$ assimilation rate $\left(\mathrm{A}_{\mathrm{CO} 2}\right)$ were unaffected by the application of physical materials, but differed for ABA and AVG. Compared with untreated control plants, ABA reduced $g_{\mathrm{s}}(47 \%$ to $69 \%)$ and $\mathrm{A}_{\mathrm{CO} 2}(37 \%$ to $57 \%)$ by the end of the second water deficit cycle, whereas AVG increased $g_{s}(27 \%$ to $60 \%)$ during the first desiccation cycle. Leaf $\left(\psi_{\mathrm{If}}\right)$ and stem $\left(\psi_{\mathrm{st}}\right)$ xylem water potential of plants treated with film-forming materials generally decreased at the same rate as those of untreated plants, whereas application of AVG caused earlier and more pronounced decline of $\psi_{\text {If }}$. Application of ABA enabled the maintenance of $\psi_{\text {If }}$ and $\psi_{\text {st }}$ during two desiccation cycles, and thus prevented an increase of electrolyte leakage and leaf abscission. Growth rates of all plant components were reduced after ABA applications. However, allometric relationships showed similar patterns of dry matter allocation in leaves and shoots among ABA, TF, VG, and untreated control plants. Application of AS reduced allocation of dry matter to leaves, whereas AVG enhanced it at the expense of roots. These data indicate that water deficit tolerance of pepper seedlings only occurred with foliar application of ABA. This effect was associated with improved plant water relations, increased cell membrane stability, reduced leaf abscission, and a transient reduction in plant growth rates.
\end{abstract}

Transplanting is a common cultural practice used to improve stand establishment, shorten the field growing cycle, enhance earliness, and eventually increase yield and quality of vegetable crops. After transplanting, biotic and abiotic stressors acting both independently or in combination often limit seedling growth and stand establishment (Leskovar and Stoffella, 1995). Limited root absorption area upon transplanting can be the source of transient drought stress and subsequent poor stand establishment, particularly under high field evapotranspiration conditions, even

Received for publication 28 Nov. 2006. Accepted for publication 1 May 2007. Funded in part by U.S. Department of Agriculture grants (CSREES no. 200534461-15661 "Rio Grande Basin Initiative" and CSREES no. 2004-3440214768 "Designing Foods for Health"). S.G. also acknowledges financial support from the Fulbright Program for her stay at TAES-Uvalde, Texas A\&M University.

We thank S. Agehara, TAES-Uvalde, for his valuable technical help and Valent BioSciences Corp., Libertyville, IL, suppliers of the compounds, and South Cross Vegetable Transplants, Mission, TX.

Mention of a trademark, proprietary product or vendor does not constitute a guarantee or warranty of the product, nor does it imply approval or disapproval to the exclusion of other products or vendors that may also be suitable.

${ }^{1}$ Corresponding author. E-mail: d-leskovar@tamu.edu. with optimum irrigation regimes. Restricted water uptake can lead to sudden and severe plant water deficit, resulting in transplant shock (Nitzsche et al., 1991). High air temperatures, accompanied by dry winds and rapid soil drying conditions, encountered in many southern regions of the United States can also be detrimental during or right after crop establishment.

Strategies that reduce plant transpiration have the potential to enhance stand establishment. Foliar application of antitranspirants is a promising tool for regulating transpiration to maintain a favorable plant water status. Previous studies indicated that antitranspirant application can increase leaf water potential, survival, and subsequent yield when bell pepper seedlings were transplanted into the field (Berkowitz and Rabin, 1988; Nitzsche et al., 1991). Antitranspirants have different modes of action (Davenport et al., 1969; Gale and Hagan, 1966), and effective formulations are those that prevent excessive water loss without reducing $\mathrm{CO}_{2}$ uptake.

Reflective materials such as kaolin clay and chitosan can reduce absorption of radiant energy (heat), lowering leaf temperatures and reducing transpiration (Bittelli et al., 2001; Jifon and Syvertsen, 2003). Emulsions of wax, latex, or plastics that dry on 
the foliage and form thin films can also minimize escape of water from the plant by decreasing stomatal conductance $\left(g_{\mathrm{s}}\right)$ and thus preventing transpirational losses, improving plant water status, and reducing wilting and leaf abscission (Gu et al., 1996; Hummel, 1990; Laurie et al., 1994; Nitzsche et al., 1991; Plaut et al., 2004). As a result of limited gas exchange between leaf and the surrounding environment, common responses are increased leaf temperature and impaired net $\mathrm{CO}_{2}$ assimilation rate $\left(\mathrm{A}_{\mathrm{CO} 2}\right)$, but the magnitude of these responses is highly species or cultivar dependent (Laurie et al., 1994; Plaut et al., 2004; Russo and Díaz-Pérez, 2005). Regardless of the limitation of $\mathrm{A}_{\mathrm{CO} 2}$, enhanced vegetative growth of pepper, walnut (Juglans regia L.), and tomato (Lycopersicon esculentum Mill.) were reported as well (Irmak et al., 1999; Nitzsche et al., 1991; Voyiatzis and McGranahan, 1994).

Physiologically active chemicals that trigger partial or complete stomatal closure [e.g., abscisic acid (ABA) and its analogs], thus decreasing water loss from leaves, have also been used as antitranspirants (Davies and Zhang, 1991). Berkowitz and Rabin (1988) found that ABA-treated pepper transplants had higher field survival rates than untreated seedlings, which was attributed to reduced $g_{S}$ and increased leaf water potential. Under certain conditions, ABA application can also slow shoot growth (Watts et al., 1981) and can thus be used to control transplant growth in nurseries (Leskovar and Cantliffe, 1992). The shoot growth reduction effect seems to be more responsive when foliar ABA is applied to regularly watered plants compared with plants exposed to moderate water deficit (Leskovar and Cantliffe, 1992). A retardation of moisture use and growth of tomato but not in marigold (Tagetes patula L.) was also found with ABA analog $8^{\prime}$ acetylene ABA methyl ester (Sharma et al., 2005).

Sharp (2002) has suggested that an increase in endogenous ABA concentrations often may help to maintain rather than to inhibit shoot and root growth under soil drying conditions. This role was related to ABA antagonistic interaction with ethylene. Increased ethylene concentration in plant tissues, a frequent response to various environmental stresses, often triggers leaf senescence and abscission (Morgan and Drew, 1997). Inhibitors of ethylene biosynthesis such as aminoethoxyvinylglycine (AVG) may thus mitigate the ethylene-related effects of stresses (Abeles et al., 1992). Islam et al. (2003) found that application of AVG at the root zone reduced transpiration under drought stress and postponed water deficit of white pine (Pinus strobus L.) plants. Application of AVG into germination media also stimulated root and shoot growth of barley (Hordeum vulgare L.) seedlings (Locke et al., 2000).

Manipulation of transplant growth and physiology by irrigation management has been used to condition transplants to withstand posttransplant stress better (Leskovar, 1998; Liptay et al., 1998). The use of antitranspirants to condition transplants could be a safer practice that eliminates the risk of stressing young seedlings to the point of physiological injury. Most of the studies cited earlier have separately evaluated the effects of antitranspirants on physiological (water relations and gas exchange) or growth (morphology and yield) parameters. Parallel analysis of these plant responses can provide a better understanding of the potential benefits of antitranspirants for transplant conditioning. The objective of this study was to determine the effects of physical film-forming and chemical antitranspirants on growth and physiological responses contributing to stress tolerance of pepper seedlings when exposed to transient water deficit stress.

\section{Material and Methods}

Treatments AND Growth Conditions. Two experiments were conducted in a greenhouse at the Texas A\&M University, Texas Agricultural Expt. Sta. in Uvalde (lat. $29^{\circ} 1^{\prime} \mathrm{N}$, long. $99^{\circ} 5^{\prime} \mathrm{W}$ ) during April and Sept. 2005. Maximum $P P F$ within the greenhouse at the canopy level was $\approx 1500 \mu \mathrm{mol} \cdot \mathrm{m}^{-2} \cdot \mathrm{s}^{-1}$ using natural summer photoperiods. Five-week-old pepper seedlings were treated using a spray method with film-forming and chemical antitranspirants, and were then exposed to desiccation by withholding water.

The film-forming (physical) antitranspirants used were AntiStress (AS; Enviroshield Products Co., Houston, TX), Vapor Gard (VG; Miller Chemical and Fertilizer Corp., Hanover, PA), and Transfilm (TF; PBI/Gordon Corp., Kansas City, MO). The chemical antitranspirant was ABA (Valent BioSciences Co., Libertyville, IL), whereas AVG (ReTain; Abbot Laboratories, Abbott Park, IL) was used as a potential antagonist of ethylene activity. Spray solution concentrations were prepared according to manufacturer recommendations: $2.2 \%$ for $\mathrm{AS}$ and $\mathrm{VG}, 3.8 \%$ for TF, $2 \mathrm{~g} \cdot \mathrm{L}^{-1}$ for ABA, and 3.8\% for AVG. Foliar applications were done with a hand-held sprayer, and plants were sprayed until leaves were evenly covered but before dripping. Untreated control plants were sprayed with tap water.

The first experiment (small scale) addressed changes in plant height, water status, and survival of pepper seedlings exposed to one desiccation cycle. The second experiment (large scale) concentrated on the physiological behavior of seedlings exposed to two desiccation cycles. In the first experiment (Expt. 1), seeds of poblano pepper (cv. Tiburon; Sakata Seed America, Morgan Hill, CA) were sown in peat-lite mix (Speedling, Sun City, FL) and covered with a thin layer of medium-grade horticultural vermiculite. Seedlings were grown in trays (South Cross Vegetable Transplants, Mission, TX) with $35 \mathrm{~mL}$ of cell volume for 5 weeks (ready for transplanting in the field) and then sprayed with tested compounds as described earlier. Two days before the onset of treatments, seedlings were fertilized with a soluble fertilizer $30 \mathrm{~N}-4.4 \mathrm{P}-8.3 \mathrm{~K}$ (Scotts Miracle-Gro Products, Marysville, $\mathrm{OH}$ ) at a $\mathrm{N}$ rate of 100 $\mathrm{mg} \cdot \mathrm{L}^{-1}$. After spraying, plants were exposed to a desiccation period by withholding water for $11 \mathrm{~d}$. Day/night air temperatures were 21 to $25^{\circ} \mathrm{C} / 16$ to $18{ }^{\circ} \mathrm{C}$.

During the second experiment (Expt. 2), pepper seeds were sown as described before except that tray cell volume was $28 \mathrm{~mL}$. Plants of the same age as in Expt. 1 were sprayed and exposed to two 4-d water deficit cycles, the first irrigation being $4 \mathrm{~d}$ after spray and water deficit treatment (DAT) and the second, 8 DAT. Rewatering was conducted when leaves from all untreated control plants had wilted. The difference in irrigation timing between the two experiments was the result of higher air temperatures in Expt. 2, with day/night temperatures of 25 to $40{ }^{\circ} \mathrm{C} / 18$ to $20^{\circ} \mathrm{C}$. During the course of the experiments, seedling flats were rotated across greenhouse benches to avoid position effects.

Growth MEASUREMENTS AND ANALYSIS. Plant height from the substrate level to the shoot apex was measured before treatment application and at 3 and 6 DAT in Expt. 1 and at 4, 8, and 19 DAT in Expt. 2. A total of 60 plants/treatment were used, avoiding plants from edge rows. Thirty additional plants per treatment were harvested at 4 and $8 \mathrm{DAT}$, and were partitioned into leaves, stems, and roots. Leaf area (LA) was measured using LI-3100 (LI-COR, Lincoln, NE). Roots were carefully washed free of rooting medium, separated into segments, and 
spread out in a transparent tray containing a thin layer of water. Roots were scanned with a digital image analysis system at a resolution of 300 dots per inch and root length was determined (WinRhizo LA 1600; Régent Instruments, Québec, Canada). All tissues were oven-dried at $70{ }^{\circ} \mathrm{C}$ until constant weight and dry weights recorded.

WATER POTENTIAL AND RELATIVE WATER CONTENT. Midday (1100-1500 HR) stem and leaf xylem water potential were measured with a Scholander-type pressure bomb (Soil Moisture Equipment Corp., Santa Barbara, CA). Stem xylem water potential $\left(\psi_{\mathrm{st}}\right)$ was measured $3,4,7$, and $8 \mathrm{DAT}$, whereas leaf water potential $\left(\psi_{1 \mathrm{f}}\right)$ was measured $2,3,4,6$, and 8 DAT. At least six plants per treatment were cut at the base of the transplant and $\psi_{\text {st }}$ was measured immediately. On a separate set of plants, the first fully developed leaf, about the third or fourth leaf from the apex, was excised and used for $\psi_{1 \mathrm{ff}}$ measurements. Relative water content (RWC) was determined on leaves of the same age as those used for $\psi_{1 \mathrm{f}}$. From each of the six plants, an entire leaf was collected and its fresh weight (FW) was recorded. The leaves were rehydrated in distilled water in the dark for $20 \mathrm{~h}$ to obtain the turgid weight (TW). Leaves were then dried in an oven until constant weight and dry weights were determined (Turner, 1981). The RWC expressed as percent was calculated as

$$
\mathrm{RWC}=100 \times[(\mathrm{FW}-\mathrm{DW}) /(\mathrm{TW}-\mathrm{DW})]
$$

Electrolyte leakage. Leaves of about the same age as those sampled for $\psi_{1 \mathrm{f}}$ and RWC measurements were used for the electrolyte leakage (EL) determination by a modified procedure described previously (Lutts et al., 1996). Two leaves per replication were taken for each treatment, and EL was determined for the whole leaf. Leaves were washed with three changes of deionized water and incubated in sealed vials filled with $10 \mathrm{~mL}$ deionized water and slowly shaken in a water bath at $25^{\circ} \mathrm{C}$. Electrical conductivity of the solution containing the leaves was measured after $24 \mathrm{~h}\left(\mathrm{EC}_{1}\right)$, and then autoclaved at $120{ }^{\circ} \mathrm{C}$ and $103.1 \mathrm{MPa}$ for $20 \mathrm{~min}$. The second conductivity reading $\left(\mathrm{EC}_{2}\right)$ was obtained upon equilibration at $25^{\circ} \mathrm{C}$. The $\mathrm{EL}$ expressed as percent was calculated as

$$
\mathrm{EL}=\mathrm{EC}_{1} /\left(\mathrm{EC}_{1}+\mathrm{EC}_{2}\right)
$$

Gas exchange measurements. Net photosynthesis $\left(\mathrm{A}_{\mathrm{CO} 2}\right)$, stomatal conductance $\left(g_{\mathrm{s}}\right)$, intercellular $\mathrm{CO}_{2}$ concentration $\left(\mathrm{C}_{\mathrm{i}}\right)$, and leaf temperature were determined with a portable photo- synthesis system (LI-6200; LI-COR) equipped with a $0.25-\mathrm{L}$ chamber using a constant leaf area $\left(2.5 \mathrm{~cm}^{2}\right)$. Fully developed and sun-exposed leaves from five to seven plants per treatment were selected for measurements during midday (1100-1500 HR) at 1, 4, 5, and 8 DAT. All measurements were made under natural ambient weather conditions on clear sunny days with a $P A R$ of 1200 to $1450 \mu \mathrm{mol} \cdot \mathrm{m}^{-2} \cdot \mathrm{s}^{-1}$, air temperature of 35 to $40{ }^{\circ} \mathrm{C}$, relative humidity of $40 \%$ to $63 \%$, and an air vapor pressure of 2.4 to $4.1 \mathrm{kPa}$.

EXPERIMENTAL DESIGN AND STATISTICAL ANALYSIS. The experiments were conducted using a randomized complete block design with three replications. General linear models procedures (SAS Institute, Cary, NC) were used for statistical analyses. Data were tested for normality of distribution and homogeneity of variance, and were transformed when necessary.

Effect of treatment on plant height was analyzed by the analysis of covariance, with initial plant height measured at the day of the treatment as the covariate. Treatment effects on plant growth and biomass allocation were examined by calculating relative growth rates (RGRs) for root, stem, leaves, shoot (stem + leaf), and plant dry weight (root + shoot), as well as for root length and LA growth rate for the period between 4 and 8 DAT (Hunt, 1982). Data for calculated RGR values, $\mathrm{A}_{\mathrm{CO} 2}, g_{\mathrm{s}}, \psi_{\mathrm{lf}}, \psi_{\mathrm{st}}, \mathrm{RWC}$, EL, leaf abscission, and survival were subjected to analysis of variance using PROC GLM with the SAS software, and mean separation was determined by the LSD test.

Allometric relationships between seedling components were calculated to separate further the treatment effects from size effects as plants grew (Gebauer et al., 1996). For each treatment, the amount of total biomass allocated to a plant component was described by the allometric equation

$\log _{\mathrm{e}}($ component dry weight $)=b_{0}+b_{1} \log _{\mathrm{e}}($ plant dry weight $)$

where $b_{0}$ and $b_{1}$ are constants. The slope $b_{1}$ is the allometric coefficient and it represents the relative change in allocation of dry matter to specific organs. When interactions between treatments and $\log _{\mathrm{e}}$ (plant dry weight) were significant, differences among slopes were tested using the Tukey-Kramer test.

\section{Results}

Growth AND WATER STATUS (ExPT. 1). Plant height was significantly reduced with $\mathrm{ABA}$ and $\mathrm{AVG}$ compared with control 3 and 6 DAT, whereas plant height was similar for

Table 1. Effect of abscisic acid (ABA), aminoethoxyvinylglycine (AVG), and film-forming materials on plant height, relative water content

\begin{tabular}{|c|c|c|c|c|c|c|c|}
\hline \multirow[b]{3}{*}{ Treatment $^{z}$} & \multicolumn{7}{|c|}{ Time after treatment (d) } \\
\hline & 3 & 6 & 6 & 8 & 6 & 8 & 11 \\
\hline & \multicolumn{2}{|c|}{ Plant ht $(\mathrm{cm})$} & \multicolumn{2}{|c|}{ RWC (\%) } & \multicolumn{2}{|c|}{ EL $(\%)$} & Survival (\%) \\
\hline Control & $11.0 \mathrm{a}^{\mathrm{y}}$ & $11.4 \mathrm{a}$ & $98.4 \mathrm{a}$ & $50.1 \mathrm{~b}$ & $8.3 \mathrm{a}$ & $33.2 \mathrm{~b}$ & $0 \mathrm{c}$ \\
\hline AVG & $10.7 \mathrm{~b}$ & $11.1 \mathrm{~b}$ & $95.7 \mathrm{ab}$ & $51.3 \mathrm{~b}$ & $8.8 \mathrm{a}$ & $20.5 \mathrm{~b}$ & $22 \mathrm{~b}$ \\
\hline AntiStress & $11.0 \mathrm{a}$ & $11.4 \mathrm{a}$ & 89.9 b & $52.5 \mathrm{~b}$ & $14.1 \mathrm{a}$ & $45.2 \mathrm{a}$ & $11 \mathrm{~b}$ \\
\hline Transfilm & $10.8 \mathrm{ab}$ & $11.1 \mathrm{~b}$ & $96.2 \mathrm{ab}$ & $47.5 \mathrm{~b}$ & $10.4 \mathrm{a}$ & $17.1 \mathrm{~b}$ & $11 \mathrm{~b}$ \\
\hline
\end{tabular}
(RWC), electrolyte leakage (EL), and survival of pepper seedlings exposed to a single water deficit cycle (Expt. 1).

zPlants were treated with water (control), abscisic acid (ABA; Valent BioSciences Co., Libertyville, IL), aminoethoxyvinylglycine (AVG, ReTain; Abbot Laboratories, Abbott Park, IL), AntiStress (Enviroshield Products Co., Houston, TX), Transfilm (PBI/Gordon Corp., Kansas City, MO), or Vapor Gard (Miller Chemical and Fertilizer Corp., Hanover, PA) and exposed to a single 8-d water deficit cycle.

${ }^{\mathrm{y}}$ Means within a column followed by the same letter are not significantly different according to LSD test at $P \leq 0.05$. 
AS, VG, and control treatments (Table 1). At 6 DAT, untreated control plants were able to maintain a high RWC (98.4\%) as other treated plants and higher than AS (89.9\%). As the water deficit progressed to $8 \mathrm{~d}$, only ABA-treated plants were able to maintain higher leaf RWC (90.9\%) with less EL (7.8\%) compared with other treatments (Table 1). Severe water stress caused complete drying and death of control plants, and significant reduction for all other treatments except for ABA, which enabled 100\% survival (Table 1).

Gas exchange (Expt. 2). During the course of this experiment, $g_{\mathrm{s}}$ was not changed $(P>0.05)$ by the application of AS, $\mathrm{TF}$, and VG compared with the control (Fig. 1A). Application of ABA sharply decreased $g_{\mathrm{s}}$ from $0.864 \mathrm{~mol} \cdot \mathrm{m}^{-2} \cdot \mathrm{s}^{-1}$ (not shown)
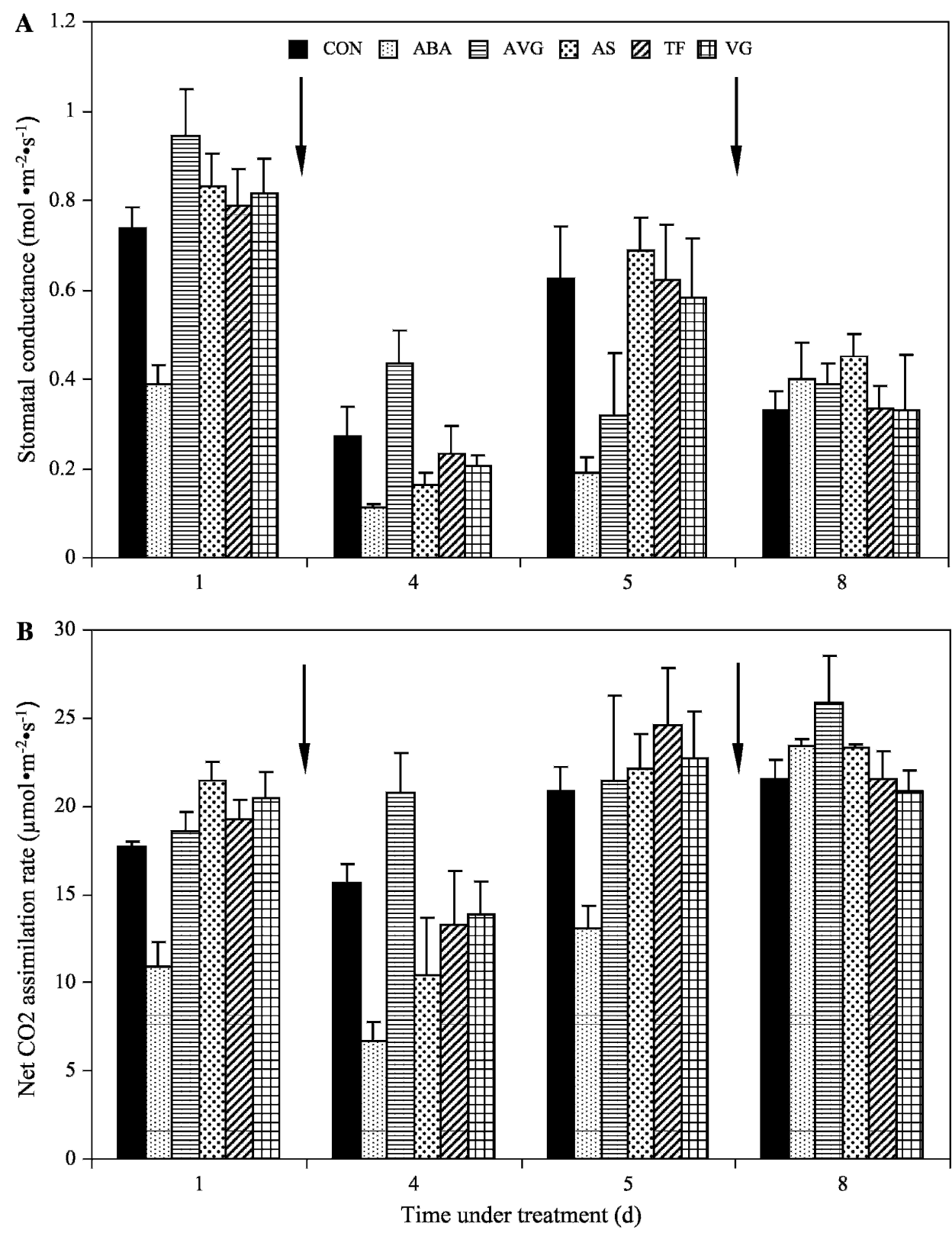

Fig. 1. (A, B) Stomatal conductance $(\mathbf{A})$ and net $\mathrm{CO}_{2}$ assimilation rate $(\mathbf{B})$ of pepper seedlings treated with abscisic acid (ABA, Valent BioSciences Co., Libertyville, IL), aminoethoxyvinylglycine (AVG, as ReTain, Abbott Laboratories, Abbott Park, IL), AntiStress (AS; Enviroshield Products Co., Houston, TX), Vapor Gard (VG; Miller Chemical and Fertilizer Corp., Hanover, PA), Transfilm (TF; PBI/Gordon Corp., Kansas City, MO), or water $(\mathrm{CON})$ and exposed to two 4-d water deficit cycles $(0-4 \mathrm{~d}, 4-8 \mathrm{~d})$. Arrows indicate irrigation events (fourth and eighth day). Vertical bars indicate mean $\pm \mathrm{SE}(\mathrm{n}=5-7)$. measured before treatment to $0.390 \mu \mathrm{mol} \cdot \mathrm{m}^{-2} \cdot \mathrm{s}^{-1} 1 \mathrm{DAT}$, and it stayed lower compared with all other treatments $(P \leq 0.05)$ up to 8 DAT. Conversely, AVG application increased $g_{\mathrm{s}}$ compared with control or ABA treatment 1 DAT and with all other treatments 4 DAT (Fig. 1A).

Net $\mathrm{CO}_{2}$ assimilation rate measured before treatment applications was $20.5 \mu \mathrm{mol} \cdot \mathrm{m}^{-2} \cdot \mathrm{s}^{-1}$, (not shown) and after $24 \mathrm{~h}$ of withholding water it stayed in the range of 17.7 to 21.4 $\mu \mathrm{mol} \cdot \mathrm{m}^{-2} \cdot \mathrm{s}^{-1}$ for all treatments except for ABA-treated plants (Fig. 1B). Depression of $\mathrm{A}_{\mathrm{CO} 2}$ by $\mathrm{ABA}$ application in comparison with other treatments $(P \leq 0.05)$ was present until 5 DAT, and it increased up to the control level after the second rewatering period 8 DAT.

Antitranspirant spray treatments did not influence $\mathrm{C}_{\mathrm{i}}$ concentration (data not shown) except at 5 DAT, when the $\mathrm{C}_{\mathrm{i}}$ of the AVG-treated plants $\left(193 \mu \mathrm{mol} \cdot \mathrm{mol}^{-1}\right)$ was significantly lower $(P \leq 0.05)$ in comparison with control $\left(263 \mu \mathrm{mol} \cdot \mathrm{mol}^{-1}\right)$, AS (277 $\left.\mu \mathrm{mol} \cdot \mathrm{mol}^{-1}\right)$, TF (259 $\left.\mu \mathrm{mol} \cdot \mathrm{mol}^{-1}\right)$, and VG (246 $\left.\mu \mathrm{mol} \cdot \mathrm{mol}^{-1}\right)$. On the same day, $\mathrm{C}_{\mathrm{i}}$ concentration was lower for ABA (217 $\left.\mu \mathrm{mol} \cdot \mathrm{mol}^{-1}\right)$ compared with control and AS-treated plants. Differences between leaf and air temperature were not significant (data not shown).

WATER POTENTIAL AND RELATIVE WATER CONTENT (EXPT. 2). Leaf water potential measured at the day of application averaged $-0.14 \mathrm{MPa}$ across treatments (not shown) and decreased after $2 \mathrm{~d}$ of water deficit for all treatments (Fig. 2A). The decrease of $\psi_{1 \mathrm{f}} 2$ DAT was most pronounced for AVG-treated plants $(-1.15 \mathrm{MPa})$ followed by VG $(-0.95$ $\mathrm{MPa})$ and $\mathrm{TF}(-0.85 \mathrm{MPa})$. Untreated control plants maintained $\psi_{1 \mathrm{lf}}$ at the same level $(P>0.05)$ as plants treated with $\mathrm{AS}, \mathrm{TF}$, and $\mathrm{VG}$, except 3 DAT (Fig. 2A). Leaf water potential of ABA-treated plants remained more than $-0.37 \mathrm{MPa}$ during the course of the experiment, and it was higher $(P \leq 0.05)$ compared with other treatments except at days of rewatering (4 and 8 DAT). Stem water potential was not significantly affected by the treatments, except that $\psi_{\text {st }}$ of ABA-treated plants was higher 3 and 7 DAT compared with other treatments (Fig. 2B).

Relative water content of ABAtreated plants was significantly higher than that of the other treatments during both drying cycles when measured 3 and 7 DAT (Fig. 3A). Overall leaf RWC measured 7 DAT was $\approx 25 \%$ lower than at 3 DAT. 

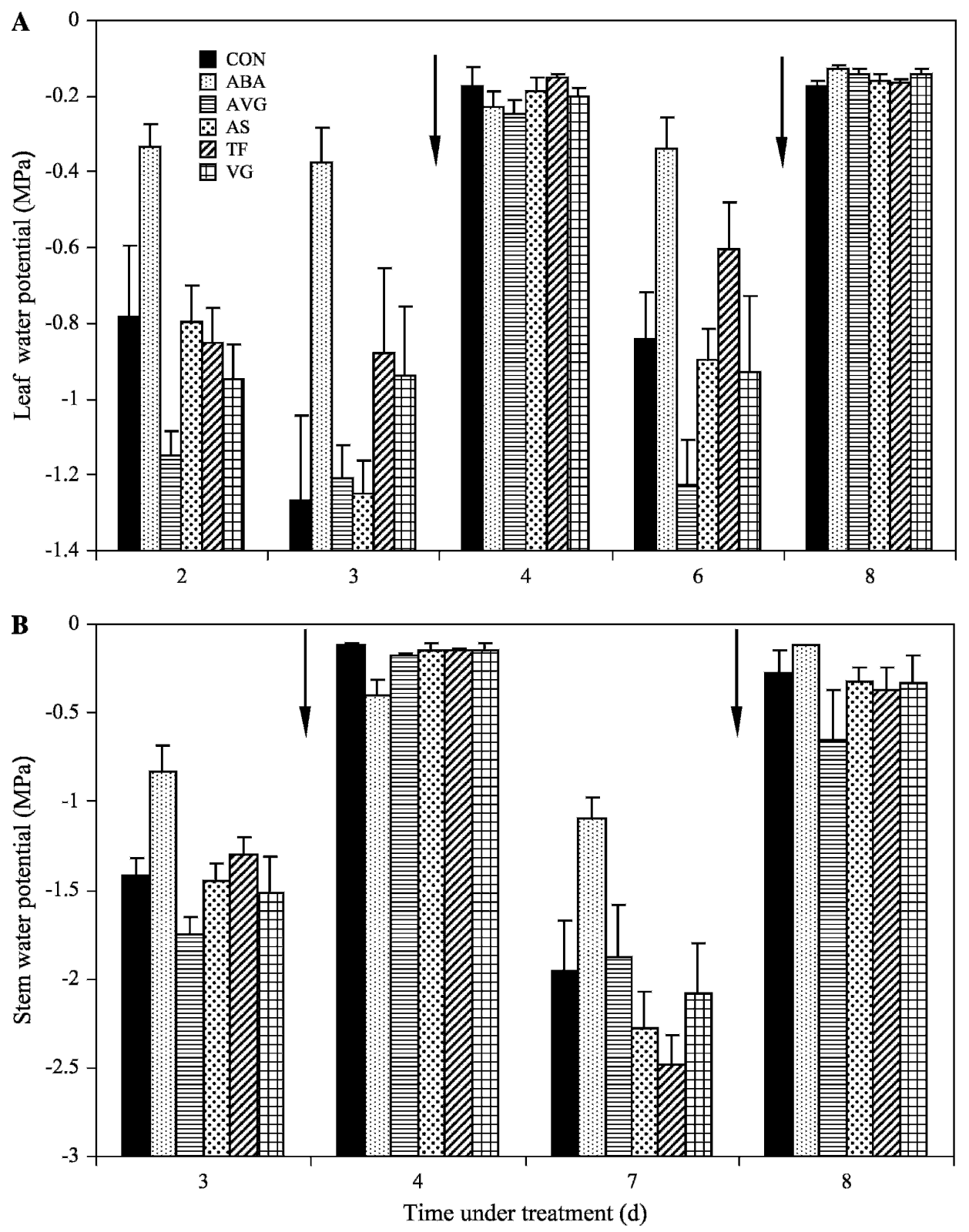

Fig. 2. (A, B) Leaf (A) and stem (B) xylem water potential of pepper seedlings treated with abscisic acid (ABA, Valent BioSciences Co., Libertyville, IL), aminoethoxyvinylglycine (AVG, as ReTain, Abbott Laboratories, Abbott Park, IL), AntiStress (AS; Enviroshield Products Co., Houston, TX), Vapor Gard (VG; Miller Chemical and Fertilizer Corp., Hanover, PA), Transfilm (TF; PBI/Gordon Corp., Kansas City, MO), or water (CON) and exposed to two 4-d water deficit cycles (0-4 d, 4-8 d). Arrows indicate irrigation events (fourth and eighth day). Vertical bars indicate mean \pm SE $(n=6)$

Plant Growth (Expt. 2). Plant height was generally unaffected by antitranspirant treatments, although a slight increase was observed in TF- and VG-treated plants compared with untreated, and ABA- and AVG-treated plants 4 DAT and 8 DAT (Fig. 3B), but these differences disappeared 19 DAT. Application of ABA and AVG had the most pronounced reduction in leaf abscission compared with control and filmforming materials 4 and 8 DAT (Fig. 3C).

Root RGR was unaffected by application of film-forming materials, but was reduced for ABA- and AVG-treated plants to $40 \%$ and $50 \%$, respectively, compared with control plants (Table 2). Enhanced stem RGR was found after AVG and VG application, whereas ABA and TS reduced it significantly compared with control. Application of $\mathrm{ABA}$ and $\mathrm{AS}$ reduced leaf RGR compared with control and other treatments, whereas shoot RGR was also reduced for ABA-, AS-, and TF-treated plants, but increased with AVG and VG treatments. Similarly, total RGR was significantly reduced with $\mathrm{ABA}, \mathrm{TF}$, and $\mathrm{AVG}$.

Root length and leaf area RGR were significantly reduced for all treatments, except for AVG, compared with the control (Table 2). Aminoethoxyvinylglycine-treated plants showed higher stem and shoot RGR than control; but, as a result of reduced root RGR, they had lower total plant RGR.

Allometric analyses revealed treatment differences in dry matter allocation to below- and aboveground plant parts (Table 3 ). Plants treated with AS allocated more biomass to stems $\left(b_{1}=0.489\right)$ at the expense of leaves $\left(b_{1}=0.298\right)$. Aminoethoxyvinylglycine-treated plants allocated more biomass to leaves $\left(b_{1}=0.662\right)$ at the expense of root production $\left(b_{1}=0.107\right)$. Plants treated with ABA, VG, and control had similar allocation patterns to each other, whereas TF had more allocation to roots and less to stems compared with control.

\section{Discussion}

Film-forming materials. The film-forming antitranspirants used in the current study (AS, TF, and $\mathrm{VG})$ did not significantly influenced leaf gas exchange $\left(\mathrm{A}_{\mathrm{CO} 2}, g_{\mathrm{s}}\right.$, or $\left.\mathrm{C}_{\mathrm{i}}\right)$ and water relations of pepper seedlings exposed to water deficit stress when compared with control untreated seedlings. Leaf and stem xylem water potential of plants treated with all film-forming materials decreased at the same rate as those of untreated plants (Fig. 2). In both experiments, no improvement in RWC or reduction of cell membrane injury was found with the application of film-forming materials.

Plaut et al. (2004) found that acrylic film application decreased $g_{\mathrm{s}}$ and $\mathrm{A}_{\mathrm{CO} 2}$ of greenhouse-grown pepper plants. Differences in leaf and plant age, as well as the imposition of water deficit stress, might explain the responses of their study and ours. Seedlings typically have much smaller leaves and may not yet be as physiologically competent and responsive to treatments as fully developed leaves from mature plants. Developing leaves from seedlings may also be more susceptible to injury, as suggested by the decrease in leaf area RGR for all film-forming materials. This was most pronounced for AS 

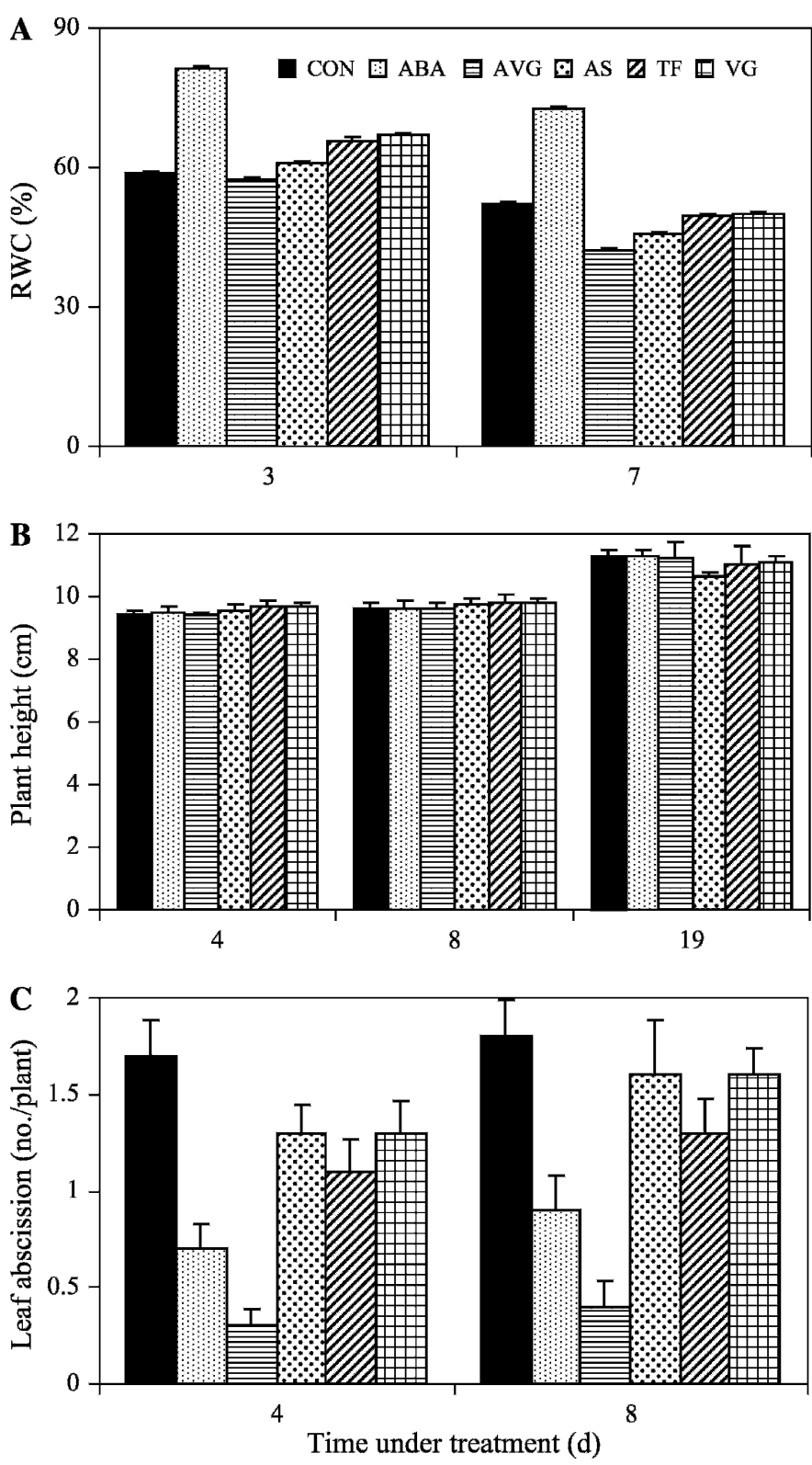

Fig. 3. (A-C) Relative water content [RWC (A)], plant height (B), and leaf abscission $(\mathbf{C})$ of pepper seedlings treated with abscisic acid (ABA, Valent BioSciences Co., Libertyville, IL), aminoethoxyvinylglycine (AVG, as ReTain, Abbott Laboratories, Abbott Park, IL), AntiStress (AS; Enviroshield Products Co., Houston, TX), Vapor Gard (VG; Miller Chemical and Fertilizer Corp., Hanover, PA), Transfilm (TF; PBI/Gordon Corp., Kansas City, MO), or water $(\mathrm{CON})$ and exposed to two 4-d water deficit cycles $(0-4 \mathrm{~d}, 4-8 \mathrm{~d})$. Vertical bars indicate mean \pm 1 SE $(n=6$ for $\mathrm{RWC}, \mathrm{n}=18$ for plant height and leaf abscission).

(Tables 2 and 3), although leaf abscission was similar to other film-forming treatments and control. Irmak et al. (1999) reported that VG reduced transpiration and increased the vegetative growth of tomato plants. This is in agreement with our findings, because VG enhanced stem growth rate and positively affected shoot growth rate compared with control. It is highly possible that variability in species/cultivar responses to film-forming materials, as reported for ornamentals, woody, desert or horticultural crops (Hummel, 1990, Laurie et al., 1994; Plaut et al., 2004), could explain the differences between studies. Film-forming antitranspirants act as a physical barrier to water lost from leaves and thus they are primarily active in the adaxial leaf surface. If spray methods could ensure uniform coverage on both the adaxial/abaxial epidermal leaf surfaces, the potential for reducing water loss through stomata could be greater to what was observed.

AMinoethoXYvinYLGLYCINE AND ABSCISIC ACID. In contrast to film-forming materials, ABA and AVG were probably translocated within plant tissues, and both compounds had more influence on the physiology and growth of pepper seedlings exposed to desiccation stress. An enhancement of $g_{\mathrm{s}}$ by AVG compared with untreated plants was measured in the absence of visible water stress 1 DAT, and immediately after rewatering 4 DAT (Fig. 1). This suggests that by blocking ethylene production, AVG induced stomatal opening, as previously reported (Tissera and Ayres, 1986). In addition, a significant decline in $\psi_{1 f}$ for AVG-treated plants measured 2 and 6 DAT suggests that AVG may have interfered with regulation of stomatal function during water deficit stress, whereas other treated plants were only under moderate water deficit stress. The lower $g_{\mathrm{s}}$ of AVG-treated plants compared with control and film-forming materials 5 DAT is probably a result of "overcompensation" for excessive water loss (Gu et al., 1996). In contrast to the $g_{\mathrm{s}}$ responses to $\mathrm{AVG}, \mathrm{A}_{\mathrm{CO} 2}$ did not changed significantly throughout the drying cycles (Fig. 1). However, $\mathrm{A}_{\mathrm{CO} 2}$ levels of AVGtreated plants were higher than those of controls (2\% to $33 \%$ ), depending on day of measurement. The enhanced leaf dry matter allocation and leaf area RGR at the expense of root mass allocation and root growth (Tables 2 and 3) raises the question of AVG allocation within plants. Root-applied AVG can modify processes at the shoot level (Islam et al., 2003; Leskovar et al., 2006; Locke et al., 2000); however, whether shootapplied AVG influences root growth is unknown. The reduction in whole-plant RGR of AVG-treated plants (almost 30\% compared with control) was probably a consequence of excessive water loss that resulted from the lower capacity of those plants to regulate stomata closure during water stress. Maintenance of a favorable plant water status is crucial for expansive growth and overall dry matter accumulation.

The reduced leaf abscission by both AVG and ABA treatments (Fig. 3C) may have occurred possibly through interactive mechanisms. It is known that AVG reduces ethylene production and thus prevents leaf abscission (Abeles et al., 1992). On the other hand, ABA-induced stomatal closure can prevent leaf dehydration, senescence, and abscission. In addition, ABA possibly limited the extent of ethylene synthesis, as was found for jack pine (Pinus banksana Lamb.) seedlings, and citrus (Citrus sinensis L.) plants (Gómez-Cadenas et al., 2002; Rajasekaran and Blake, 1999). The decrease of EL observed in ABA- but not in AVG-treated plants (Table 1) also suggests that ethylene evolution is not the only factor contributing to membrane damage under desiccation stress (Rajasekaran and Blake, 1999). Enhanced osmotic adjustment and higher turgor pressure and hence leaf $\psi_{1 \mathrm{f}}$ and RWC in ABA-treated leaves may also be important in membrane protection under drought stress (Wang et al., 2003).

Stomatal conductance for ABA-treated plants compared with untreated plants decreased significantly from $47 \% 1$ DAT to $60 \% 5$ DAT; however, the magnitude of this change diminished after the second rewatering $8 \mathrm{DAT}$. A significant but less pronounced trend was also measured for $\mathrm{A}_{\mathrm{CO} 2}$. Because $\mathrm{Ci}$ concentration of $\mathrm{ABA}$-treated plants was not changed in 
Table 2. Effect of abscisic acid (ABA), aminoethoxyvinylglycine (AVG), and film-forming materials on relative growth rate (RGR) of root, stem, leaf, shoot and total plant weight, root length, and leaf area of pepper seedlings exposed to two water deficit cycles (Expt. 2).

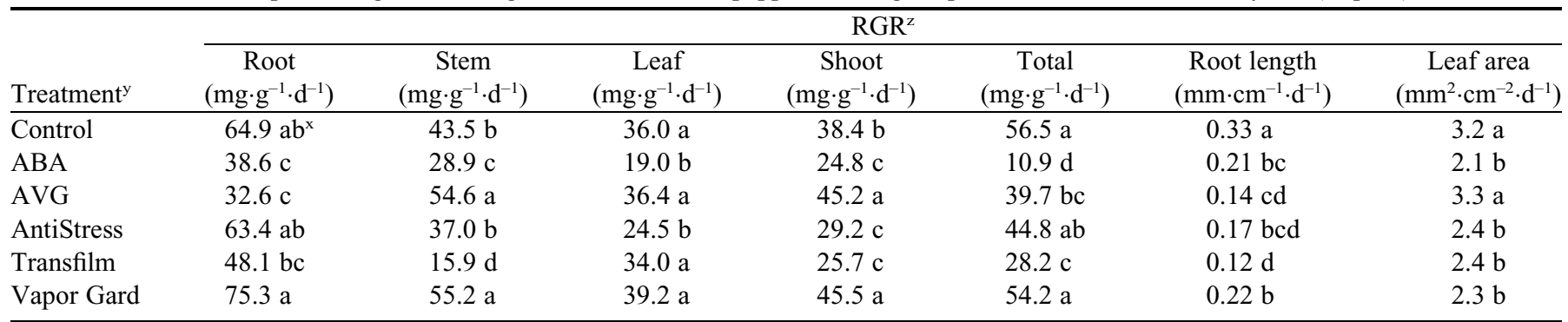

${ }^{\mathrm{z}}$ Relative growth rate (RGR) for all parameters was calculated as growth rate achieved between two rewatering periods, 4 and $8 \mathrm{~d}$ after treatment. yPlants were treated with water (control), abscisic acid (ABA; Valent BioSciences Co., Libertyville, IL), aminoethoxyvinylglycine (AVG, ReTain; Abbot Laboratories, Abbott Park, IL), AntiStress (Enviroshield Products Co., Houston, TX), Transfilm (PBI/Gordon Corp., Kansas City, MO), or Vapor Gard (Miller Chemical and Fertilizer Corp., Hanover, PA) and exposed to two 4-d water deficit cycles (0-4 d, 4-8 d).

${ }^{\mathrm{x}}$ Means within a column followed by the same letter are not significantly different according to LSD test at $P \leq 0.05$.

Table 3. Allometric coefficients $\left(b_{1}\right)$ for biomass distribution among plant tissues of pepper seedlings as affected by antitranspirant treatment and water deficit exposure (Expt. 2).

\begin{tabular}{lllll}
\hline & \multicolumn{4}{c}{ Y } \\
\cline { 2 - 5 } Treatment $^{\mathrm{z}}$ & Root & \multicolumn{4}{c}{ Stem } & Leaf & Shoot \\
\cline { 2 - 5 } Control $^{4} \mathrm{~b}_{1}{ }^{\mathrm{y}}$ & $0.163 \mathrm{~b}^{\mathrm{x}}$ & $0.351 \mathrm{~b}$ & $0.494 \mathrm{~b}$ & $0.841 \mathrm{ab}$ \\
ABA & $0.242 \mathrm{ab}$ & $0.334 \mathrm{~b}$ & $0.430 \mathrm{~b}$ & $0.762 \mathrm{~b}$ \\
AVG & $0.107 \mathrm{c}$ & $0.239 \mathrm{bc}$ & $0.662 \mathrm{a}$ & $0.896 \mathrm{a}$ \\
AntiStress & $0.221 \mathrm{ab}$ & $0.489 \mathrm{a}$ & $0.298 \mathrm{c}$ & $0.783 \mathrm{~b}$ \\
Transfilm & $0.339 \mathrm{a}$ & $0.139 \mathrm{c}$ & $0.530 \mathrm{~b}$ & $0.666 \mathrm{~b}$ \\
Vapor Gard & $0.175 \mathrm{~b}$ & $0.322 \mathrm{~b}$ & $0.510 \mathrm{~b}$ & $0.828 \mathrm{ab}$ \\
\hline
\end{tabular}

${ }^{2}$ Plants were treated with water (control), abscisic acid (ABA; Valent BioSciences Co., Libertyville, IL), aminoethoxyvinylglycine (AVG, ReTain; Abbot Laboratories, Abbott Park, IL), AntiStress (Enviroshield Products Co., Houston, TX), Transfilm (PBI/Gordon Corp., Kansas City, MO), or Vapor Gard (Miller Chemical and Fertilizer Corp., Hanover, PA) and exposed to two 4-d water deficit cycles $(0-4 \mathrm{~d}, 4-8 \mathrm{~d})$.

${ }^{y}$ Values of $b_{1}$ were obtained from the relationship: $\log _{\mathrm{e}} \mathrm{y}=\mathrm{b}_{0}+\mathrm{b}_{1}$ $\log _{\mathrm{e}} \mathrm{x}$, where $\mathrm{x}$ is the total plant dry weight and $\mathrm{y}=$ dry weight of the tissue under consideration.

${ }^{x}$ Different letters within column indicate a difference among slopes $\left(\mathrm{b}_{1}\right)$ by Tukey-Kramer test at $P \leq 0.05$.

comparison with control, except at 5 DAT, it seems that stomatal functioning was not the only limiting factor for $\mathrm{A}_{\mathrm{CO} 2}$ (Jifon and Syvertsen, 2003). Abscisic acid might have had a nonstomatal influence on biochemical changes during the photosynthetic reaction (Popova et al., 1996). A decrease in $g_{\text {s }}$ and $\mathrm{A}_{\mathrm{CO} 2}$ after $\mathrm{ABA}$ application was observed as soon as $1 \mathrm{~h}$ after treating french bean (Phaseolus vulgaris L.), sugar beet (Beta vulgaris L.), and maize (Zea mays L.) (Pospisilova and Batkova, 2004). The same effect was found in well-watered or drought-stressed barley and poplar (Populus L.) plants (Popova et al., 1996; Yin et al., 2004).

Reduced RGR of root and all shoot growth components in ABA-treated plants led to $80 \%$ reduction of total RGR compared with control plants (Table 2). However, patterns of root and shoot biomass accumulation were similar to those of control plants (Table 3). Because the ABA-induced reduction in RGR is transient, this further confirms the potential use of ABA to control transplant growth in nurseries (Leskovar and Cantliffe, 1992).
In summary, application of film-forming antitranspirants during water deficit stress did not significantly affect physiological or growth parameters of pepper seedlings. Treatment with AVG resulted in increased $g_{\mathrm{s}}$ and reduced $\psi_{1 \mathrm{f}}$ and total plant growth despite a reduction in leaf abscission. The potential of AVG as an antitranspirant seems limited because the excessive water loss resulting from increased $g_{\mathrm{s}}$ would predispose the newly transplanted seedlings to dehydration, retarded growth, and poor establishment. The ABA-induced transient reduction in $g_{\mathrm{s}}$ (and presumably transpirational water loss) could potentially protect seedlings from desiccation injury associated with transplant shock by allowing plants to conserve water. Further research across species aiming at the potential application of natural ABA, or ABA analogs having similar physiological effects, would make this approach economically feasible for large-scale industry use.

\section{Literature Cited}

Abeles, F.B., P.W. Morgan, and M.E. Saltveit. 1992. Ethylene in plant biology. Academic Press, San Diego, CA.

Berkowitz, G.A. and J. Rabin. 1988. Antitranspirant associated abscisic-acid effects on the water relations and yield of transplanted bell peppers. Plant Physiol. 86:329-331.

Bittelli, M., M. Flury, G.S. Campbell, and E.J. Nichols. 2001. Reduction of transpiration through foliar application of chitosan. Agr. For. Meteorol. 107:167-175.

Davenport, D.C., R.M. Hagan, and P.E. Martin. 1969. Antitranspirants: Uses and effects on plant life. Calif. Turfgrass Cult. 19:25-27.

Davies, W.J. and J.H. Zhang. 1991. Root signals and the regulation of growth and development of plants in drying soil. Annu. Rev. Plant Physiol. Plant Mol. Biol. 42:55-76.

Gale, J. and R.M. Hagan. 1966. Plant antitranspirants. Annu. Rev. Plant Physiol. 17:269-282.

Gebauer, R.L.E., J.F. Reynolds, and B.R. Strain. 1996. Allometric relations and growth in Pinus taeda: The effect of elevated $\mathrm{CO}_{2}$ and changing N availability. New Phytol. 134:85-93.

Gómez-Cadenas, A., V. Arbona, J. Jacas, E. Primo-Millo, and M. Talon. 2002. Abscisic acid reduces leaf abscission and increases salt tolerance in citrus plants. J. Plant Growth Regul. 21:234-240.

Gu, S.L., L.H. Fuchigami, S.H. Guak, and C. Shin. 1996. Effects of short-term water stress, hydrophilic polymer amendment, and antitranspirant on stomatal status, transpiration, water loss, and growth in 'Better Boy' tomato plants. J. Amer. Soc. Hort. Sci. 121:831-837.

Hummel, R.L. 1990. Water relations of container-grown woody and herbaceous plants following antitranspirant sprays. HortScience 25:772-775. 
Hunt, R. 1982. Plant growth curves: The functional approach to plant growth analysis. Edward Arnold, London, UK.

Irmak, A., J.W. Jones, C.D. Stanley, J.W. Hansen, S. Irmak, and K.J. Boote. 1999. Some effects of an antitranspirant (Vapor Gard) on tomato growth and yield. Soil Crop Sci. Soc. Fla. Proc. 58:118-122.

Islam, M.A., T.J. Blake, F. Kocacinar, and R. Lada. 2003. Ambiol, spermine, and aminoethoxyvinylglycine prevent water stress and protect membranes in Pinus strobus L under drought. TreesStructure Function 17:278-284.

Jifon, J.L. and J.P. Syvertsen. 2003. Kaolin particle film applications can increase photosynthesis and water use efficiency of 'Ruby Red' grapefruit leaves. J. Amer. Soc. Hort. Sci. 128:107-112.

Laurie, S., M. Bradbury, and G.R. Stewart. 1994. Relationships between leaf temperature, compatible solutes and antitranspirant treatment in some desert plants. Plant Sci. 100:147-156.

Leskovar, D.I. 1998. Root and shoot modification by irrigation. HortTechnology 8:510-514.

Leskovar, D.I. and D.J. Cantliffe. 1992. Pepper seedling growthresponse to drought stress and exogenous abscisic-acid. J. Amer. Soc. Hort. Sci. 117:389-393.

Leskovar, D.I., S. Goreta, and J.A. Franco. 2006. Impact of AVG preharvest spray and soil injection on yield and quality of melon. HortScience 41:1249-1252.

Leskovar, D.I. and P.J. Stoffella. 1995. Vegetable seedling root systems: Morphology, development, and importance. HortScience 30:1153-1159.

Liptay, A., P. Sikkema, and W. Fonteno. 1998. Transplant growth control through water deficit stress: A review. HortTechnology 8:540-543.

Locke, J.M., J.H. Bryce, and P.C. Morris. 2000. Contrasting effects of ethylene perception and biosynthesis inhibitors on germination and seedling growth of barley (Hordeum vulgare L.). J. Expt. Bot. 51:1843-1849.

Lutts, S., J.M. Kinet, and J. Bouharmont. 1996. NaCl-induced senescence in leaves of rice (Oryza sativa L) cultivars differing in salinity resistance. Ann. Bot. (Lond.) 78:389-398.

Morgan, P.W. and M.C. Drew. 1997. Ethylene and plant responses to stress. Physiol. Plant. 100:620-630.

Nitzsche, P., G.A. Berkowitz, and J. Rabin. 1991. Development of a seedling-applied antitranspirant formulation to enhance water status, growth, and yield of transplanted bell pepper. J. Amer. Soc. Hort. Sci. 116:405-411.
Plaut, Z., Y. Magril, and U. Kedem. 2004. A new film forming material, which reduces water vapour conductance more than $\mathrm{CO}_{2}$ fixation in several horticultural crops. J. Hort. Sci. Biotechnol. 79:528-532.

Popova, L.P., T.D. Tsonev, G.N. Lazova, and Z.G. Stoinova. 1996. Drought- and ABA-induced changes in photosynthesis of barley plants. Physiol. Plant. 96:623-629.

Pospisilova, J. and P. Batkova. 2004. Effects of pre-treatments with abscisic acid and/or benzyladenine on gas exchange of french bean, sugar beet, and maize leaves during water stress and after rehydration. Biol. Plant. 48:395-399.

Rajasekaran, L.R. and T.J. Blake. 1999. New plant growth regulators protect photosynthesis and enhance growth under drought of jack pine seedlings. J. Plant Growth Regul. 18:175-181.

Russo, V.M. and J.C. Díaz-Pérez. 2005. Kaolin-based particle film has no effect on physiological measurements, disease incidence or yield in peppers. HortScience 40:98-101.

Sharma, N., S.R. Abrams, and D.R. Waterer. 2005. Uptake, movement, activity, and persistence of an abscisic acid analog (8'acetylene ABA methyl ester) in marigold and tomato. J. Plant Growth Regul. 24:28-35.

Sharp, R.E. 2002. Interaction with ethylene: Changing views on the role of abscisic acid in root and shoot growth responses to water stress. Plant Cell Environ. 25:211-222.

Tissera, P. and P.G. Ayres. 1986. Endogenous ethylene affects the behavior of stomata in epidermis isolated from rust infected faba bean (Vicia faba L.). New Phytol. 104:53-61.

Turner, N.C. 1981. Techniques and experimental approaches for the measurement of plant water status. Plant Soil 58:339-366.

Voyiatzis, D.G. and G.H. McGranahan. 1994. An improved method for acclimatizing tissue-cultured walnut plantlets using an antitranspirant. HortScience 29:42.

Wang, Z.L., B.R. Huang, and Q.Z. Xu. 2003. Effects of abscisic acid on drought responses of kentucky bluegrass. J. Amer. Soc. Hort. Sci. 128:36-41.

Watts, S., J.L. Rodriguez, S.E. Evans, and W.J. Davies. 1981. Root and shoot growth of plants treated with abscisic-acid. Ann. Bot. (Lond.) 47:595-602.

Yin, C.Y., B.L. Duan, X. Wang, and C.Y. Li. 2004. Morphological and physiological responses of two contrasting poplar species to drought stress and exogenous abscisic acid application. Plant Sci. 167:10911097. 